\title{
Growth rate-dependent recruitment of Japanese anchovy Engraulis japonicus in the Kuroshio-Oyashio transitional waters
}

\author{
Motomitsu Takahashi ${ }^{1, *}$, Yoshiro Watanabe ${ }^{2}$ \\ ${ }^{1}$ National Research Institute of Fisheries Science, Fisheries Research Agency, 2-12-4 Fukuura, Kanazawa-ku, Yokohama, \\ Kanagawa 236-8648, Japan \\ ${ }^{2}$ Ocean Research Institute, The University of Tokyo, 1-15-1 Minamidai, Nakano-ku, Tokyo 164-8639, Japan
}

\begin{abstract}
Based on the relationship between otolith and somatic growth rates, we examined the effect of growth and developmental rates on survival during larval and early juvenile stages in Japanese anchovy Engraulis japonicus collected in the Kuroshio-Oyashio transition region in the western North Pacific. Mean daily otolith increment width (IW) positively correlated with mean growth and developmental rates in rearing experiments. In the Kuroshio-Oyashio transition region, fastergrowing larvae with larger IWs attained completion of metamorphosis at younger ages than slowergrowing larvae. The minimum IWs in the recruited adults collected in 1999 greatly increased from $4.8 \mu \mathrm{m}$ at $40 \mathrm{~d}$ after hatching to $11.0 \mu \mathrm{m}$ at $60 \mathrm{~d}$, while the minimum IWs in the pre-recruits collected in 1998 was less than $5.0 \mu \mathrm{m}$ at $60 \mathrm{~d}$, and accounted for ca. $60 \%$ of the total pre-recruit population. Based on the positive relationship between IWs and growth rates in the rearing experiments, an IW of $11.0 \mu \mathrm{m}$ is estimated to correspond to $0.41 \mathrm{~mm} \mathrm{~d}^{-1}$ in growth rate. It was concluded that pre-recruits with growth rates $<0.41 \mathrm{~mm} \mathrm{~d}^{-1}$ at $60 \mathrm{~d}$ have a negligible probability of survival to recruitment. Mortality dependent on growth and developmental rates occurred in the metamorphosing stage of $E$. japonicus in the Kuroshio-Oyashio transition region. Since environmental conditions in the transition region are variable, and these conditions affect growth and developmental rates of larvae, the rates in the metamorphosing stage could determine the abundance of recruited $1 \mathrm{yr}$ old E. japonicus in the transition region.
\end{abstract}

KEY WORDS: Growth rate $\cdot$ Survival $\cdot$ Otolith increment width $\cdot$ Metamorphosis $\cdot$ Japanese anchovy

\section{INTRODUCTION}

Survival processes during the early life stages in fishes have been studied in order to understand recruitment dynamics since Hjort (1914) postulated the 'critical period' hypothesis, which stated that food limitation during a short period after the yolk absorption affects the subsequent survival rate and eventual recruitment. Anderson (1988) proposed the 'growth-mortality' hypothesis that the bigger larvae of a faster growth rate in a population metamorphose from the larval to the juvenile stage at a younger age, and have a higher probability of surviving to recruitment. The concept of the 'growth-mortality' hypothesis has been supported in many fishes after rearing experiments and field studies were carried out. Bigger larvae have been shown to have a higher tolerance to starvation and a higher ability to escape from predators than smaller larvae in rearing experiments (Miller et al. 1988, Baily \& Houde 1989). In field studies, faster-growing larvae survived better than slower-growing larvae until the juvenile stage (Meekan \& Fortier 1996, Hare \& Cowen 1997). In highly fecund marine fish, growth rates during the larval and juvenile stages can, therefore, be an important factor regulating the survival rate in early life stages and subsequent recruitment success/failure.

The finding that growth increment in fish otolith is deposited on a daily basis (Pannella 1971) laid the foun- 
dation for early life-history studies of fishes on a daily basis. In the Japanese anchovy Engraulis japonicus, seasonal and geographical variability in larval growth rates have been reported in the spawning and nursery grounds in Japanese coastal waters (Tsuji 1983, Sigel 1988, Mitani 1990). It is, however, often difficult to count and measure all the daily growth increments in adult otoliths, since there are many areas where indistinct increments are deposited. The widths of otolith daily increments during the larval stage have been shown to be correlated with the somatic daily growth and metabolic rates in many fishes (Wright 1991, Moksness et al. 1995, Paperno et al. 1997). Comparison of the growth trajectory based on the otolith increment widths between recruited survivors and the original population can, therefore, be used to evaluate the growth requirements during the early life stages for recruitment success.

The distribution of Engraulis japonicus eggs expanded from the Pacific coastal waters off central Japan to the offshore Kuroshio axis with the increase in population size in the early 1990s (Zenitani \& Asano 1996). Most of eggs and larvae were found to have been transported eastward by the Kuroshio Current from the coastal spawning ground to the Kuroshio Extension (Kasai et al. 1992, Heath et al. 1998), and into the Kuroshio-Oyashio transition region by the northward intrusion of warm water from the Kuroshio Extension (Okazaki et al. 2002). The main nursery and feeding grounds were concluded to shift from the coastal waters to the eastern offshore waters off northern Japan with the increase in population size. Larval, juvenile and adult E. japonicus were distributed in the eastern offshore waters off northern Japan, the Kuroshio-Oyashio transition region, in the 1950s and 1990s when the population sizes were large (Odate 1957, Takahashi et al. 2001). The distribution range of the Japanese sardine Sardinops melanostictus have also been shown to expand during periods of large population size to the eastern offshore waters in the transition region and subarctic waters (Kuroda 1991). The abundance of recruits at Age 1 in these small pelagic fishes during the period when population size is large could therefore be dependent on the growth and survival processes in the young-of-the-year stage in the Kuroshio-Oyashio transition region.

The Kuroshio-Oyashio transition region has irregularly distributed eddies and complex thermohaline fronts between the Kuroshio Extension and the subarctic Oyashio fronts (Kawai 1972). The average biomass of copepods is greater in the northern part of the transi- tion region dominated by cold-water species than in the southern part dominated by warm-water species (Odate 1994). Growth and developmental rates of larval Engraulis japonicus were faster in the SW waters than in the northern or eastern waters in the transition region (Takahashi 2001). In the spatially and temporally variable environments in the transition region, the probability of an E. japonicus larva surviving to recruitment will be variable, depending on the environmental conditions in which it occurs.

The objective of this study was to evaluate the consequences of growth- and developmental rate variability during early life stages on the recruitment success of Engraulis japonicus in the Kuroshio-Oyashio transition region, by comparing the growth history during the larval stage between pre-recruits (larvae and early juveniles) and recruits (adults). We reared E. japonicus from the late larval to early juvenile stage through metamorphosis under different conditions of water temperature and feeding. We used the results from the rearing experiments to interpret the data from the field study in order to determine the suitable environmental conditions for recruitment success during the early life stages in the Kuroshio-Oyashio transition region.

\section{MATERIALS AND METHODS}

Field study. Sample processing: Engraulis japonicus were collected by subsurface trawls in the Kuroshio-Oyashio transition region aboard R/V 'TanshuMaru' of the National Research Institute of Fisheries Science, from mid-May to mid-June in 1998 and 1999 (Table 1, Fig. 1). The net had a square opening of $25 \times$ $25 \mathrm{~m}$ and a cod end with a $1.0 \mathrm{~cm}$-mesh aperture. Three trawl hauls a night were made with the bottom of the net opening at depths shallower than $25 \mathrm{~m}$. Subsamples of 200 to 300 larvae and early juveniles, and ca. 100 adults, were sorted out randomly from each trawl catch and preserved at $-25^{\circ} \mathrm{C}$.

Table 1. Engraulis japonicus. Collection data of pre-recruits in 1998 and recruits in 1999 in the Kuroshio-Oyashio transition region

\begin{tabular}{|c|c|c|c|c|c|c|}
\hline \multirow[t]{3}{*}{ Area } & \multicolumn{3}{|c|}{ Pre-recruits } & \multicolumn{3}{|c|}{ Recruits } \\
\hline & \multirow{2}{*}{$\begin{array}{l}\text { No. of } \\
\text { hauls }\end{array}$} & \multicolumn{2}{|c|}{ No. of catch } & \multirow{2}{*}{$\begin{array}{l}\text { No. of } \\
\text { hauls }\end{array}$} & \multicolumn{2}{|c|}{ No. of catch } \\
\hline & & Min. & Max. & & Min. & Max. \\
\hline $140-145^{\circ} \mathrm{E}$ & 2 & 0 & 140000 & 4 & 490 & 8000 \\
\hline $145-150^{\circ} \mathrm{E}$ & 8 & 0 & 420000 & 12 & 20 & 7700 \\
\hline $150-155^{\circ} \mathrm{E}$ & 6 & 40 & 440000 & 10 & 10 & 6700 \\
\hline $155-160^{\circ} \mathrm{E}$ & 9 & 10 & 130000 & 14 & 320 & 19000 \\
\hline $160-165^{\circ} \mathrm{E}$ & 5 & 500 & 140000 & 4 & 0 & 0 \\
\hline $165-170^{\circ} \mathrm{E}$ & 7 & 0 & 51000 & & & \\
\hline $170-175^{\circ} \mathrm{E}$ & 7 & 0 & 95000 & & & \\
\hline $175-180^{\circ} \mathrm{E}$ & 8 & 0 & 10 & & & \\
\hline
\end{tabular}


Random samples up to 100 larvae and early juveniles and 100 adults were taken from the subsamples of each station for the analysis of growth. Standard lengths (SL) were measured to the nearest $0.1 \mathrm{~mm}$ with digital calipers. Each larval and early juvenile Engraulis japonicus was assigned to 1 of the 3 developmental stages based on the degree of guanine deposition on the peritoneal and trunk surface; Gu-0 for fish at the early metamorphosing stage from larva to juvenile with no guanine deposition, Gu-1 for fish at the end of the metamorphosing stage with guanine deposition on the peritoneal surface but not on the trunk surface, and Gu-2 for juveniles with guanine deposition on the peritoneal and trunk surface (Takahashi \& Watanabe in press). Takahashi \& Watanabe (in press) showed that SL of the Gu-1 stage fish ranged from 26 to $47 \mathrm{~mm} \mathrm{SL}$, with an average of $34 \mathrm{~mm}$ SL. The smallest possible SL of sexual maturation was ca. $100 \mathrm{~mm}$ in E. japonicus in the Kuroshio-Oyashio transition region (Takahashi et al. 2001, Funamoto \& Aoki 2002). We defined late larval and early juvenile E. japonicus $<50 \mathrm{~mm}$ SL as 'pre-recruits' and E. japonicus $>100 \mathrm{~mm}$ SL as 'recruits' that survived through the larval and juvenile stages up to recruit to the adult population in this study.

The number of pre-recruits and recruits collected in each trawl haul were enumerated by the gravimetric method based on wet weight and fish counts in subsamples. Sagittal otoliths were removed from up to 50 random specimens out of the 100 individuals for both the pre-recruits and recruits in each station, cleaned under a binocular dissecting microscope, and mounted on a glass slide with enamel resin of fingernail polish medium. Otoliths of the Gu-2 stage pre-recruits and
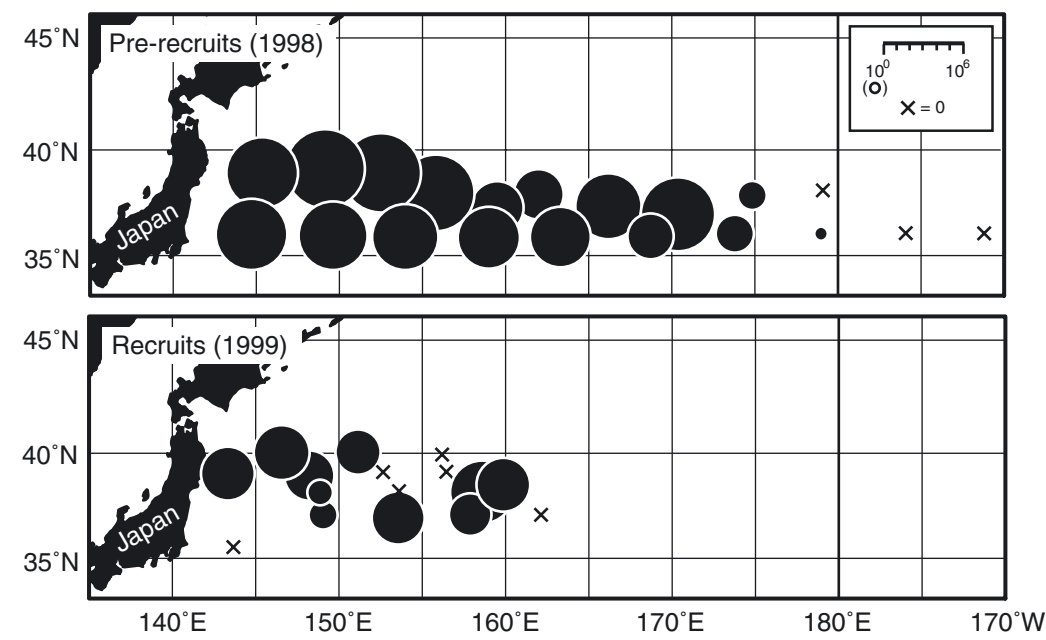

Fig. 1. Engraulis japonicus. Distribution of the pre-recruits and the recruits collected in 1998 and 1999, respectively, in the KuroshioOyashio transition region in the western North Pacific. 0 : sum of estimated number of E. japonicus caught by the 3 trawl hauls a night (scales on top panel). $\times$ : no collection of pre-recruits or recruits the recruits were ground with 2000-grit sandpaper and polished with 10000-grit lapping film in the sagittal plane until the core was clearly visible.

Otolith measurement and growth analysis: Up to 10 otoliths of pre-recruits of the Gu-0, Gu-1, Gu-2 stages and of recruits were randomly taken from 50 specimens of each trawl station. Enumeration of the growth increments and measurement of increment widths (IW) were conducted along a postrostrum transect of each otolith under a light microscope at $100 \times$ to $500 \times$ magnification with the otolith measurement system (RATOC System Engineering) controlled using a personal computer. Total number of otoliths examined in this study were 561 for pre-recruits and 90 for recruits.

As metamorphosis starts at ca. $20 \mathrm{~mm}$ SL and is completed in the Gu-1 stage (Takahashi \& Watanabe in press), the mean larval growth rate $(G)$ from hatch to catch was calculated for fish at the Gu-1 stage as:

$$
G=(L-2.7) / d_{\text {catch }}
$$

The mean growth rate in the metamorphosing period $\left(G_{\mathrm{m}}\right)$, from age at back-calculated SL of $20 \mathrm{~mm}$ to catch, was calculated for fish at the Gu-1 stage:

$$
G_{\mathrm{m}}=(L-20) /\left(d_{\text {catch }}-d_{20 \mathrm{~mm}}\right)
$$

where $L$ is the SL at catch, 2.7 is the SL at hatch (Fukuhara 1983), $d_{\text {catch }}$ and $d_{20 \mathrm{~mm}}$ are ages at catch and at $20 \mathrm{~mm}$ SL, respectively. We determined the allometric parameters of the relationship between SL and otolith radius for each Gu-1 stage fish by using the biological intercept method (Campana 1990, Campana \& Jones 1992), and back-calculated SL at ages following the method detailed in Watanabe \& Kuroki (1997). SL at the first feeding stage (first daily increment deposition) was reported to be $3.76 \pm 0.29 \mathrm{~mm}$ SL (Fukuhara 1983). We defined SL at the first daily increment deposition as $3.5 \mathrm{~mm}$ within this range in this study.

Comparison of growth history between pre-recruits and recruits: We could not backcalculate the larval growth rate of adult Engraulis japonicus because the otolith radius-SL relationship changes from an allometric relationship in the larval stage to a linear relationship after metamorphosis to juvenile, and it was not possible to determine the SL at the flexion point from allometric to linear phases of the relationship. IWs were positively correlated with growth rates during larval stage (see 'Results'). IW in recruits increased with age and reached a maximum at ca. $50 \mathrm{~d}$ after hatching and then decreased with age, while in pre-recruits IW increased with age up to capture (see 'Results'). IW in the central area of the otolith from the first 
increment to the maximum IW in the recruits was considered to represent the growth history from hatch to the end of metamorphosis. We compared the growth histories between the pre-recruits and the recruits in terms of IW in the larval and metamorphosing stage.

Rearing experiment. Larval Engraulis japonicus were caught with a boat seine net $(43 \times 3 \mathrm{~m})$ of $1.0 \mathrm{~cm}$ mesh in the Nebama Beach in Otsuchi Bay in northern Japan, carefully scooped with seawater in a 201 bucket, and immediately transported to the Otsuchi Marine Research Center of the Ocean Research Institute, University of Tokyo, on 14 July 1999 and on 18 July 2000. A sample of 100 larvae was preserved at $-30^{\circ} \mathrm{C}$ to measure SL and determine the developmental stages based on the degree of guanine deposition at the start of rearing experiment in each year. Out of the 100 individuals, 50 specimens were selected and aged using the number of otolith increments.

Rearing conditions: The larvae were stocked under conditions of ambient water temperature (18.2 to $19.4^{\circ} \mathrm{C}$ ) and photoperiod with food (Artemia fed daily in excess) in 3 black tanks (200 l) for 2 to $3 \mathrm{~d}$ after capture. About 25 larvae were transferred to each of black experimental tanks (30 1) at a density of 0.7 to 0.9 ind. $\mathrm{l}^{-1}$, and reared for $20 \mathrm{~d}$. We considered the first half of the $20 \mathrm{~d}$ rearing period as an acclimatization period to the experimental conditions, and the second half as the experimental period. The larvae were reared under 12 experimental conditions: 3 water temperatures $\left(13,17,21^{\circ} \mathrm{C}\right)$ by 4 feeding regimes $\left(0,30,300,3000\right.$ Artemia nauplii fish $\left.{ }^{-1} \mathrm{~d}^{-1}\right)$. Experiments of the $13^{\circ} \mathrm{C}$ group were conducted in 1999 and those of the 17 and $21^{\circ} \mathrm{C}$ groups in 2000. The larvae consumed all nauplii supplied in a day in each experimental condition, except for the $13^{\circ} \mathrm{C}$ and 3000 nauplii fish ${ }^{-1} \mathrm{~d}^{-1}$ group. About $20 \%$ of the water in each 301 tank was replaced every day by water filtered through a $20 \mu \mathrm{m}$-mesh net. In order to prevent disturbance to the larvae, rearing water was mildly circulated by means of water flow produced by aeration in an L-shaped PVC pipe. A. salina cysts were incubated in strongly aerated seawater at $28^{\circ} \mathrm{C}$ for 24 h. Newly hatched Artemia nauplii were enriched with the DHA-rich Aquaran (BASF Japan) at $22^{\circ} \mathrm{C}$ for $20 \mathrm{~h}$. The experimental fish were fed with the enriched Artemia nauplii 3 times a day to make up the total amount of food mentioned above. The $20 \mathrm{~d}$ reared larvae were sampled from 08:00 to $12: 00 \mathrm{~h}$ in 1999 and 2000.
Otolith/somatic growth analysis: Reared larvae were preserved at $-30^{\circ} \mathrm{C}$ for growth and developmental analysis. The SL of each fish was measured to the nearest $0.1 \mathrm{~mm}$ with digital calipers and was macroscopically assigned to 1 of the 3 guanine deposition stages. Otolith processing and measurement followed the procedures used in the field study. As there was a lagged response of ca. $1 \mathrm{wk}$ in otolith growth rate to the changes in environmental conditions (Secor et al. 1989, Moksness et al. 1995), we considered that mean IWs deposited during the second half of the $20 \mathrm{~d}$ rearing period $\left(\mathrm{IW}_{\text {exp }}\right)$ represented otolith growth under the experimental conditions and those deposited in the $10 \mathrm{~d}$ period before the experiment as the initial otolith growth before the experiment ( $\left.\mathrm{IW}_{\text {ini }}\right)$, and calculated for each fish:

$$
\begin{aligned}
& \mathrm{IW}_{\text {exp }}=\left(R_{\text {last }}-R_{\text {last-10 }}\right) / 10 \\
& \mathrm{IW}_{\text {ini }}=\left(R_{\text {last-20 }}-R_{\text {last-30 }}\right) / 10
\end{aligned}
$$

where $R_{\text {last }}, R_{\text {last-10, }}, R_{\text {last-20 }}$ and $R_{\text {last-30 }}$ are the radii from the otolith nucleus to the last increments at the margin, and the last 10,20, and 30 increments before the last increment, respectively.

Mean growth rate during the second half of the $20 \mathrm{~d}$ rearing period $\left(G_{\exp }\right)$ was calculated as:

$$
G_{\text {exp }}=\left(L_{\text {last }}-L_{\text {last-10 }}\right) / 10
$$

where $L_{\text {last }}$ and $L_{\text {last-10 }}$ are back-calculated SLs at the last increment deposition and that of the last 10 increments before the last increment following the method in the field study, respectively. Daily growth increments (discontinuous zone) in an otolith are formed at dawn in many fishes (Mugiya et al. 1981, Tanaka et al. 1981). In order to eliminate the effects of sampling time

Table 2. Engraulis japonicus. Mean standard length (SL) and growth rates in the entire larval stage $(G)$ and in the metamorphosing period $\left(G_{\mathrm{m}}\right)$ of the Gu-1 stage (see 'Sample processing' for details) pre-recruits in 4 age classes $\left(\mathrm{Cl}_{35} \ldots \mathrm{Cl}_{65}\right.$; see 'Otolith and somatic growth of the Gu-1 stage pre-recruits' for details. ns: not significant

\begin{tabular}{|llrcccccc|}
\hline \multirow{2}{*}{ Age class } & \multirow{2}{*}{$\mathrm{N}$} & Mean & $\mathrm{SD}$ & \multicolumn{7}{c|}{ Level of significance (\%) } \\
& & & & $\mathrm{Cl}_{35}$ & $\mathrm{Cl}_{45}$ & $\mathrm{Cl}_{55}$ & $\mathrm{Cl}_{65}$ \\
\hline $\mathrm{SL}(\mathrm{mm})$ & $\mathrm{Cl}_{35}$ & 18 & 31.1 & 1.73 & & & \\
& $\mathrm{Cl}_{45}$ & 25 & 32.8 & 3.14 & $\mathrm{~ns}$ & & \\
& $\mathrm{Cl}_{55}$ & 100 & 33.1 & 2.82 & 0.01 & $\mathrm{~ns}$ & \\
& $\mathrm{Cl}_{65}$ & 19 & 36.9 & 3.76 & 0.01 & 0.01 & 0.01 \\
$\mathrm{G}\left(\mathrm{mm} \mathrm{d}^{-1}\right)$ & $\mathrm{Cl}_{35}$ & 18 & 0.83 & 0.07 & & & \\
& $\mathrm{Cl}_{45}$ & 25 & 0.63 & 0.07 & 0.01 & & \\
& $\mathrm{Cl}_{55}$ & 100 & 0.55 & 0.06 & 0.01 & 0.01 & \\
& $\mathrm{Cl}_{65}$ & 19 & 0.54 & 0.05 & 0.01 & 0.01 & $\mathrm{~ns}$ \\
$G_{\mathrm{m}}\left(\mathrm{mm} \mathrm{d}^{-1}\right)$ & $\mathrm{Cl}_{35}$ & 18 & 0.98 & 0.11 & & & \\
& $\mathrm{Cl}_{45}$ & 25 & 0.68 & 0.11 & 0.01 & & \\
& $\mathrm{Cl}_{55}$ & 100 & 0.60 & 0.08 & 0.01 & 0.01 & \\
& $\mathrm{Cl}_{65}$ & 19 & 0.53 & 0.06 & 0.01 & 0.01 & 0.01 \\
\hline
\end{tabular}


on otollith radius, we defined the time of the last increment deposition as the standardized end of the experimental period.

\section{RESULTS}

\section{Field study}

Distribution of Engraulis japonicus in the Kuroshio-Oyashio transition region

The maximum number of pre-recruits collected in a trawl haul ranged from 130000 to 440000 , and was ca. 10- to 70 -fold greater than that of recruits in the waters from 35 to $40^{\circ} \mathrm{N}, 140$ to $160^{\circ} \mathrm{E}$ (Table 1, Fig. 1). The pre-recruits ranged from 17.5 to $49.7 \mathrm{~mm}$ SL (mean \pm SD: $32.7 \pm 5.9 \mathrm{~mm} \mathrm{SL}$ ) and 27 to $86 \mathrm{~d}$ after hatching $(51.9 \pm 11.5 \mathrm{~d})$. The recruits ranged from 103.7 to $139.7 \mathrm{~mm}$ SL $(120.2 \pm 7.0 \mathrm{~mm})$. Otolith increments in the recruits became indistinct after ca. $80 \mathrm{~d}$, so we used data from 1st to ca. 80th increment for the recruits.

Otolith and somatic growth of the Gu-1 stage pre-recruits

Pre-recruits in the Gu-0, Gu-1 and Gu-2 stages were classified into 7 age classes of $10 \mathrm{~d}$ intervals: $21-30 \mathrm{~d}$ $\left(\mathrm{Cl}_{25}\right), 31-40 \mathrm{~d}\left(\mathrm{Cl}_{35}\right), \ldots, 81-90 \mathrm{~d}\left(\mathrm{Cl}_{85}\right)$. More than $80 \%$ of pre-recruits were assigned to the Gu- 0 stage in $\mathrm{Cl}_{25}$

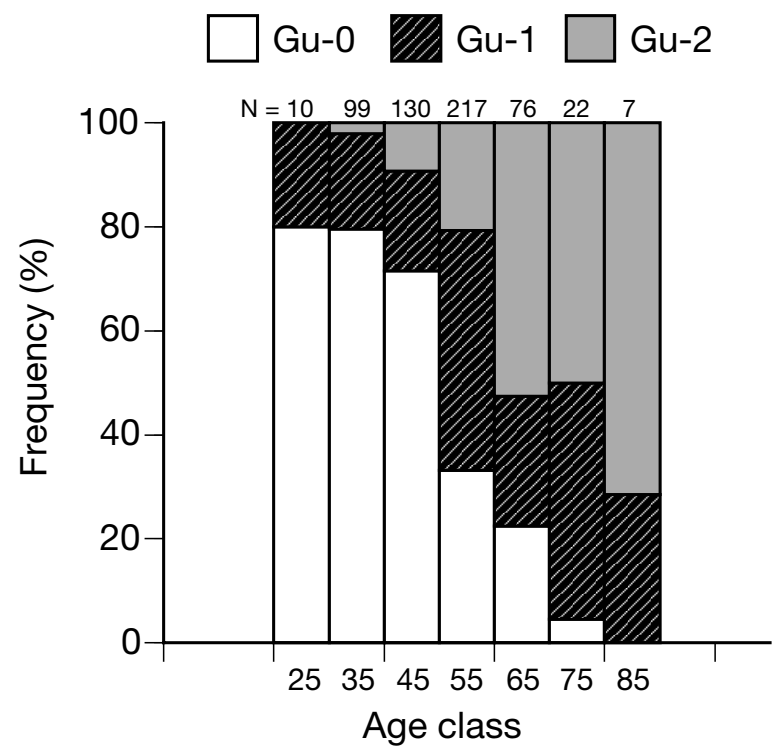

Fig. 2. Engraulis japonicus. Proportion in number of the prerecruits in the Gu-0, Gu-1 and Gu-2 stages (see 'Sample processing' for details) in each age class (see 'Otolith and somatic growth of the Gu-1 stage pre-recruits' for details) and $\mathrm{Cl}_{35}$. The proportion of the Gu-0 stage fish sharply decreased in $\mathrm{Cl}_{55}$ and older age classes (Fig. 2). Less than $20 \%$ of pre-recruits were assigned to the Gu-2 stage in $\mathrm{Cl}_{55}$ and younger age classes. The proportion of the Gu-2 stage fish sharply increased in $\mathrm{Cl}_{65}$ and older age classes. The number of pre-recruits in $\mathrm{Cl}_{25}$, $\mathrm{Cl}_{75}$ and $\mathrm{Cl}_{85}$ were less than 10 and were excluded from further analysis.

Age of the Gu-1 stage fish ranged from 29 to $83 \mathrm{~d}$ $(54.2 \pm 10.2 \mathrm{~d}) . \mathrm{SL}$ of the Gu-1 stage fish ranged from 26.4 to $47.0 \mathrm{~mm}(34.0 \pm 3.9 \mathrm{~mm})$. Mean growth rates through the larval stage $(G)$ and in the metamorphosing period $\left(G_{\mathrm{m}}\right)$ of the Gu-1 stage fish were significantly faster in the younger age classes than in the older classes (Table 2). The mean IW of the Gu-1 stage fish in $\mathrm{Cl}_{35}$ increased from $3.53 \pm 0.81 \mu \mathrm{m}$ at $5 \mathrm{~d}$ to $13.8 \pm 2.60 \mu \mathrm{m}$ at $30 \mathrm{~d}$ (Fig. 3). The mean IW in the $\mathrm{Cl}_{65}$ gradually increased from $2.88 \pm 0.49 \mu \mathrm{m}$ at $5 \mathrm{~d}$ to
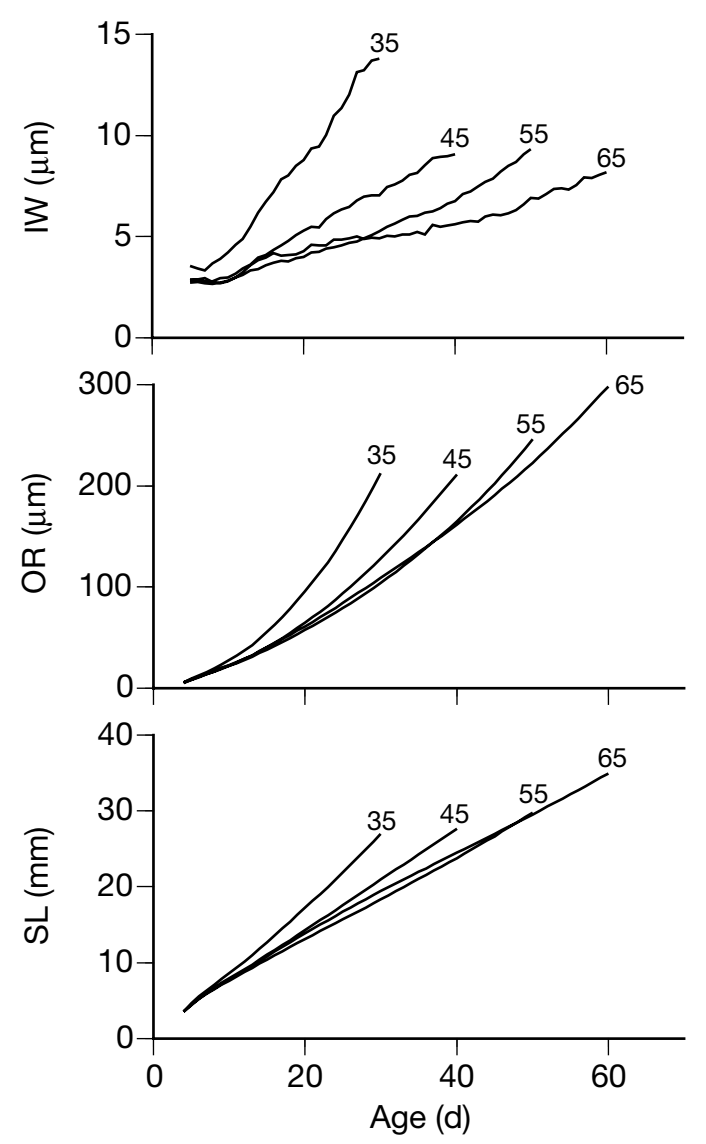

Fig. 3. Engraulis japonicus. Changes in the mean increment width (IW) (top), mean otolith radius (OR) from the otolith nucleus to the increment (middle) and mean back-calculated standard length (SL) (bottom) with age in the Gu-1 stage prerecruits (see 'Sample processing' for details) in the 4 age classes (indicated by numbers at top of lines; see 'Otolith and somatic growth of the Gu-1 stage pre-recruits' for age-class details) 


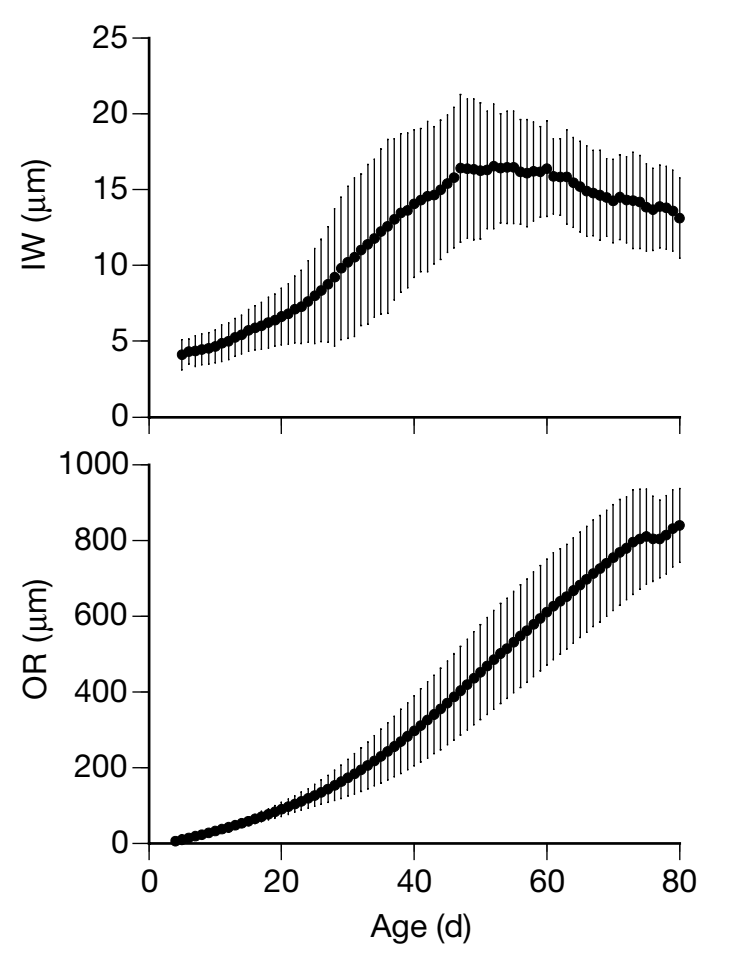

Fig. 4. Engraulis japonicus. Changes in the mean increment width (IW) (top) and mean otolith radius (OR) from the otolith nucleus to the increment (middle) with age in the recruits. Vertical bars indicate \pm SD
$4.91 \pm 0.93 \mu \mathrm{m}$ at $30 \mathrm{~d}$. Mean otolith radius (OR) from the otolith nucleus to the increment deposited at $30 \mathrm{~d}$ in $\mathrm{Cl}_{35}(213 \pm 32.5 \mu \mathrm{m})$ was 2 -fold greater than in $\mathrm{Cl}_{65}$ $(109 \pm 15.2 \mu \mathrm{m})$. Mean back-calculated SL at $30 \mathrm{~d}$ was $27.0 \pm 2.63 \mathrm{~mm}$ in $\mathrm{Cl}_{35}$, significantly larger than that in $\mathrm{Cl}_{65}(19.4 \pm 2.08)$.

\section{Larval growth history of pre-recruits and recruits of Engraulis japonicus}

Mean IW of the recruits increased from $3.93 \pm 1.29 \mu \mathrm{m}$ at $5 \mathrm{~d}$ to $16.2 \pm 4.48 \mu \mathrm{m}$ at $50 \mathrm{~d}$ and gradually decreased to $13.0 \pm 2.65 \mu \mathrm{m}$ at $80 \mathrm{~d}$ (Fig. 4). Ages at the peak of IW ranged from 31 to $79 \mathrm{~d}$, and averaged to $52.6 \pm 10.5 \mathrm{~d}$ in the 90 recruits examined. Mean OR at $30 \mathrm{~d}$ in the recruits was $173 \pm 48.1 \mu \mathrm{m}$, and was significantly larger than those in $\mathrm{Cl}_{45}, \mathrm{Cl}_{55}$ and $\mathrm{Cl}_{65}$ of the $\mathrm{Gu}-1$ stage pre-recruits, but smaller than that in $\mathrm{Cl}_{35}$.

Frequency distribution of IW were compared between pre-recruits in the $\mathrm{Gu}-0, \mathrm{Gu}-1, \mathrm{Gu}-2$ stages and recruits at 30, 40, 50, and $60 \mathrm{~d}$ (Fig. 5). The mode of IW in the recruits was 6 to $8 \mu \mathrm{m}$ and was comparable to that in the Gu-0 stage pre-recruits at $30 \mathrm{~d}$. Modes of IW in the recruits sharply increased to 14 to $16 \mu \mathrm{m}$ at $50 \mathrm{~d}$, and were larger than those in the Gu- 0 and Gu-1 pre-recruits at $40 \mathrm{~d}$ and $50 \mathrm{~d}$, respectively. Mode of IW in the recruits at $60 \mathrm{~d}$ was larger than that in the Gu-0, Gu-1 and Gu-2 pre-recruits. The proportion in total number of the pre-recruits within the IW range of recruits was $100 \%$ at $30 \mathrm{~d}$ in the $\mathrm{Cl}_{35}$, which greatly decreased to $41.3 \%$ at $60 \mathrm{~d}$ in the $\mathrm{Cl}_{65}$ (Table 3). The proportion in stage-specific number of the pre-recruits within the IW range of recruits was $100.0 \%$ in the Gu-0, Gu-1, and Gu-2 stages at $30 \mathrm{~d}$, respectively, while $0.0 \%$ in the Gu- $0,10.5 \%$ in the Gu-1 and $72.5 \%$ in the Gu-2 stage pre-recruits at $60 \mathrm{~d}$.

\section{Rearing experiment}

SLs of the late larval Engraulis japonicus used for the rearing experiments ranged from 18.9 to $27.0 \mathrm{~mm}(22.0 \pm$ $1.94)$ in 1999 and from 22.1 to $33.9 \mathrm{~mm}(28.7 \pm 3.43)$ in 2000 , respectively. Mean ages at the

Fig. 5. Engraulis japonicus. Frequency distribution of increment width (IW) in the recruits at 30,40,50 and $60 \mathrm{~d}$ and pre-recruits at $30 \mathrm{~d}$ in the $\mathrm{Cl}_{35}$ age class, and at $60 \mathrm{~d}$ in the $\mathrm{Cl}_{65}$ age class (see 'Otolith and somatic growth of the Gu-1 stage pre-recruits' for age-class details). Range of frequency is from 0 to $50 \%$ 
Table 3. Engraulis japonicus. Otolith increment width at ages in the Gu-0, Gu-1 and Gu-2 stage pre-recruits (see 'Sample processing' for details) and recruits. Percentages of the pre-recruits within the increment width (IW) ranges of the recruits are calculated. For age-class definitions, see 'Otolith and somatic growth of the Gu-1 stage pre-recruits'

\begin{tabular}{|c|c|c|c|c|c|c|c|c|c|}
\hline \multirow[t]{3}{*}{ Age } & \multicolumn{5}{|c|}{ Range of IW (mm) } & \multicolumn{4}{|c|}{$\%$ of pre-recruits within the IW range of recruits } \\
\hline & & - Pre-1 & ruits - & & Recruits & Total & & Stage & \\
\hline & Age class & $\mathrm{Gu}-0$ & Gu-1 & Gu-2 & & & $\mathrm{Gu}-0$ & $\mathrm{Gu}-1$ & $\mathrm{Gu}-2$ \\
\hline $30 \mathrm{~d}$ & $\mathrm{Cl}_{35}$ & $4.1-16.2$ & $9.7-17.2$ & $10.1-12.6$ & $3.5-30.5$ & 100.0 & 100.0 & 100.0 & 100.0 \\
\hline $40 \mathrm{~d}$ & $\mathrm{Cl}_{45}$ & $3.9-11.9$ & $6.6-16.5$ & $7.9-22.1$ & $4.8-29.7$ & 93.8 & 91.4 & 100.0 & 100.0 \\
\hline $50 \mathrm{~d}$ & $\mathrm{Cl}_{55}$ & $3.2-13.2$ & $4.6-13.6$ & $8.0-17.4$ & $7.7-33.0$ & 64.1 & 30.1 & 84.0 & 100.0 \\
\hline $60 \mathrm{~d}$ & $\mathrm{Cl}_{65}$ & $2.5-11.0$ & $5.9-11.2$ & $6.6-17.5$ & $11.0-29.5$ & 41.3 & 0.0 & 10.5 & 72.5 \\
\hline
\end{tabular}

start of the $20 \mathrm{~d}$ rearing period were $47.8 \pm 7.62 \mathrm{~d}$ in 1999 and $64.2 \pm 14.2 \mathrm{~d}$ in 2000 . In terms of the degree of guanine deposition, all the larvae in 1999 were assigned to the Gu-0 stage, while $96 \%$ of the larvae

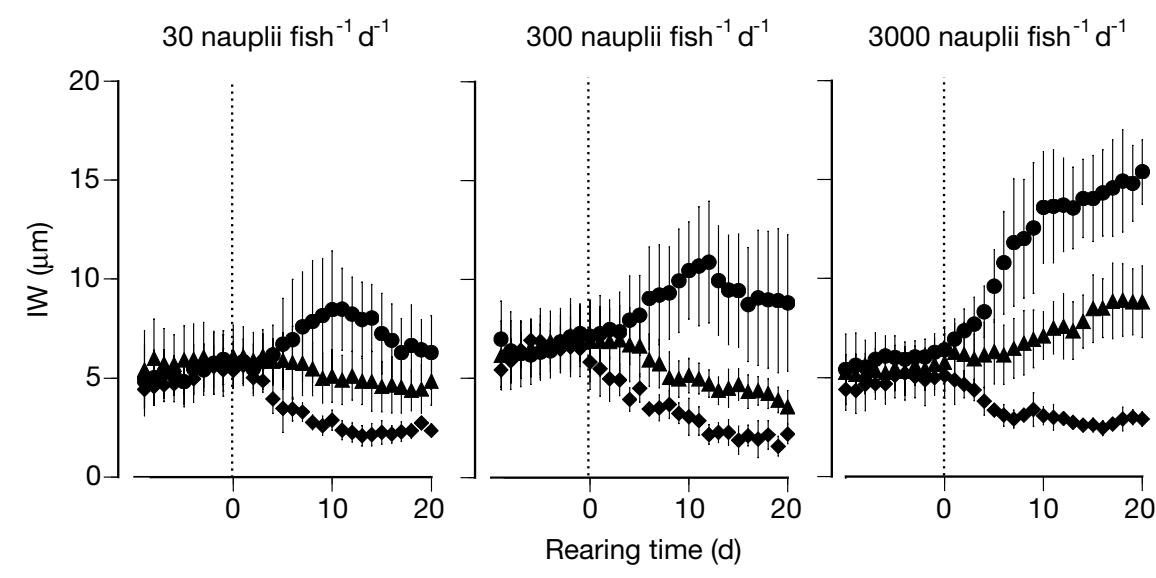

Fig. 6. Engraulis japonicus. Changes in increment width (IW) during the rearing period in the 30, 300 and 3000 nauplii fish ${ }^{-1} \mathrm{~d}^{-1}$ groups. Circles, triangles and diamonds indicate the 21,17 and $13^{\circ} \mathrm{C}$ groups, respectively. Experiments start from the dashed lines at Day 0

Table 4. Engraulis japonicus. Survival rate, mean increment width (IW; mean \pm $\mathrm{SD})$ before $\left(\mathrm{IW}_{\mathrm{ini}}\right)$ and during the second half $\left(\mathrm{IW}_{\exp }\right)$ of the $20 \mathrm{~d}$ rearing period. $N_{\text {start }}$ : number at start of rearing; $N_{\text {fin }}$ : number at end of rearing

\begin{tabular}{|c|c|c|c|c|c|c|}
\hline $\begin{array}{l}\text { Temp. } \\
\left({ }^{\circ} \mathrm{C}\right)\end{array}$ & $\begin{array}{l}\text { Food level } \\
\text { (nauplii } \\
\text { fish }^{-1} d^{-1} \text { ) }\end{array}$ & $N_{\text {start }}$ & $\begin{array}{l}\text { urviva } \\
N_{\text {fin }}\end{array}$ & $\%$ & $\mathrm{IW}_{\mathrm{ini}}$ & $\mathrm{IW}_{\exp }$ \\
\hline 13 & $\begin{array}{r}0 \\
30 \\
300 \\
3000\end{array}$ & $\begin{array}{l}20 \\
19 \\
20 \\
19\end{array}$ & $\begin{array}{l}0 \\
2 \\
3 \\
9\end{array}$ & $\begin{array}{c}0.0 \\
10.5 \\
15.0 \\
47.4\end{array}$ & $\begin{array}{l}4.9 \pm 1.2 \\
6.1 \pm 1.6 \\
4.9 \pm 0.8\end{array}$ & $2.8 \pm 0.8$ \\
\hline 17 & $\begin{array}{r}0 \\
30 \\
300 \\
3000\end{array}$ & $\begin{array}{l}25 \\
25 \\
25 \\
25\end{array}$ & $\begin{array}{l}18 \\
19 \\
22 \\
24\end{array}$ & $\begin{array}{l}72.0 \\
76.0 \\
88.0 \\
96.0\end{array}$ & $\begin{array}{l}5.8 \pm 1.6 \\
6.5 \pm 1.5 \\
5.6 \pm 1.1\end{array}$ & $\begin{array}{l}4.7 \pm 1.2 \\
4.5 \pm 0.6 \\
8.5 \pm 1.5\end{array}$ \\
\hline 21 & $\begin{array}{r}0 \\
30 \\
300 \\
3000\end{array}$ & $\begin{array}{l}25 \\
25 \\
25 \\
24\end{array}$ & $\begin{array}{l}10 \\
14 \\
18 \\
23\end{array}$ & $\begin{array}{l}40.0 \\
56.0 \\
72.0 \\
95.8\end{array}$ & $\begin{array}{l}5.4 \pm 1.1 \\
6.4 \pm 1.6 \\
6.3 \pm 0.8\end{array}$ & $\begin{array}{r}4.5 \pm 1.7 \\
9.7 \pm 2.7 \\
14.6 \pm 1.8\end{array}$ \\
\hline
\end{tabular}

were assigned to the Gu-0 stage and $4 \%$ to the Gu-1 stage in 2000.

Survival rate at the end of the $20 \mathrm{~d}$ rearing period ranged from 72 to $96 \%$ in the $17^{\circ} \mathrm{C}$ group, highest in all the temperature groups (Table 4 ). In the $21^{\circ} \mathrm{C}$ group, survival rates were $96 \%$ in the 3000 nauplii $\mathrm{d}^{-1}$ fish $^{-1}$ group, and $56 \%$ in the 30 nauplii $\mathrm{d}^{-1}$ fish $^{-1}$ group. In the $13^{\circ} \mathrm{C}$ group, survival rates were lower than $50 \%$ in all the feeding groups.

\section{IW at ages}

Mean IW deposited in the $10 \mathrm{~d}$ period before the rearing experiment (IW $\mathrm{Ini}_{\text {in }}$ ranged from 4.9 to $6.5 \mu \mathrm{m}$, and was not significantly different among the 3 feeding $\times 3$ temperature groups (Table 4, Fig. 6). Among the 3000 nauplii fish ${ }^{-1} \mathrm{~d}^{-1}$ feeding groups, mean IWs deposited during the second half of the $20 \mathrm{~d}$ rearing period ( $\mathrm{IW}_{\mathrm{exp}}$ ) were $14.6 \pm 1.8 \mu \mathrm{m}$ in the $21^{\circ} \mathrm{C}$ group, while in the $13^{\circ} \mathrm{C}$ group $\mathrm{IW}_{\exp }$ was $2.8 \pm$ $0.8 \mu \mathrm{m}$. Among the $17^{\circ} \mathrm{C}$ temperature groups, $\mathrm{IW}_{\exp }$ was $8.5 \pm 1.5 \mu \mathrm{m}$ with 3000 nauplii fish ${ }^{-1} \mathrm{~d}^{-1}$, while in the 30 and 300 nauplii fish ${ }^{-1} \mathrm{~d}^{-1}$ groups, IW $_{\text {exp }}$ were $4.7 \pm 1.2 \mu \mathrm{m}$ and $4.5 \pm 0.6 \mu \mathrm{m}$, respectively. The ratio in number of survived fish with $\mathrm{IW}_{\exp }>11 \mu \mathrm{m}$, which was the minimum IW at $60 \mathrm{~d}$ in the recruits in the field study, was $100 \%$ in the $21^{\circ} \mathrm{C}$ and 3000 nauplii fish $^{-1} \mathrm{~d}^{-1}$ group, and was higher in the groups of higher water temperature and of greater food level. As IWs in the non-fed feeding groups ( 0 nauplii fish $^{-1} \mathrm{~d}^{-1}$ ) became indistinct in the marginal area of otoliths, we excluded them from the analysis. 


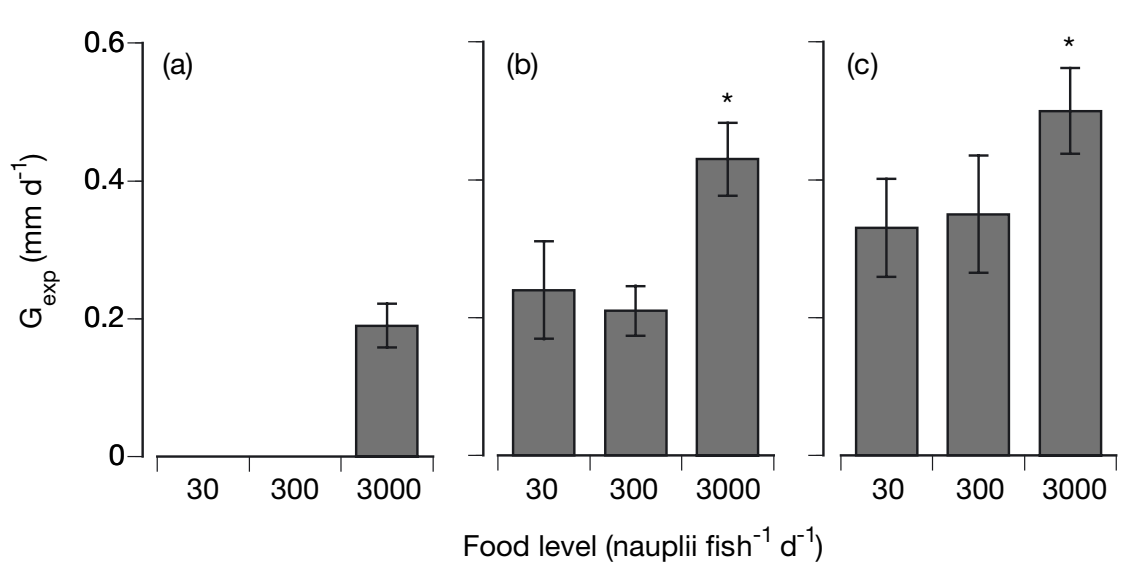

Fig. 7. Engraulis japonicus. Mean growth rates of the 3 feeding groups during the second half of the $20 \mathrm{~d}$ rearing period $\left(G_{\exp }\right)$ in the 3 temperature groups: (a) 13 , (b) 17 and (c) $21^{\circ} \mathrm{C}$. Asterisks indicate the feeding groups with significantly faster $G_{\exp }$ among each temperature groups (see 'Otolith/somatic growth analysis' for details)

\section{Mean growth rate during the experimental period}

Mean growth rates during the second half of the $20 \mathrm{~d}$ rearing period $\left(G_{\text {exp }}\right)$ in the tanks with 3000 nauplii fish $^{-1} \mathrm{~d}^{-1}$ were $0.43 \pm 0.05 \mathrm{~mm} \mathrm{~d}^{-1}$ at $17^{\circ} \mathrm{C}$ and $0.50 \pm$ $0.06 \mathrm{~mm} \mathrm{~d}^{-1}$ at $21^{\circ} \mathrm{C}$, which were significantly faster than in the tanks with 30 and 300 nauplii fish ${ }^{-1} \mathrm{~d}^{-1}$ in the respective temperature groups (Fig. 7). $G_{\exp }$ ranged from 0.13 to $0.60 \mathrm{~mm} \mathrm{~d}^{-1}$, which was positively correlated with the mean IW during the second half of the rearing period ( $\mathrm{IW}_{\exp }$ ), and was best fitted by a single linear regression $\left(G_{\text {exp }}=0.0261 \mathrm{IW}_{\text {exp }}+0.127\right.$; $\mathrm{N}=89, \mathrm{R}^{2}=0.742, \mathrm{p}<0.0001$ ) (Fig. 8).

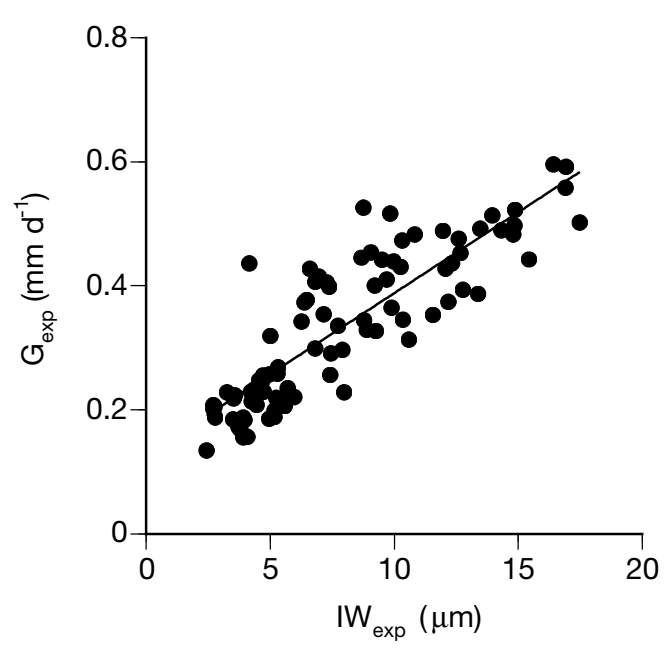

Fig. 8. Engraulis japonicus. Relationships between the mean growth rate $\left(G_{\exp }\right)$ and the mean increment width ( $\left(\mathrm{W}_{\exp }\right)$ during the second half of the $20 \mathrm{~d}$ rearing period (see 'Otolith/ somatic growth analysis' for details). Dots represent individual fish
Morphological development

The stage composition of survived fish at the end of the $20 \mathrm{~d}$ rearing period were calculated in each experimental condition, and the ratios of Gu-1 and Gu-2 in 2000 was reduced by $4 \%$ considering the variation in developmental stage at the start of the rearing experiments (Fig. 9). In the 3000 nauplii fish ${ }^{-1} \mathrm{~d}^{-1}$ feeding groups, 29.2 and $69.6 \%$ of survived fish developed to the Gu-2 stage at 17 and $21^{\circ} \mathrm{C}$, respectively. In the $13^{\circ} \mathrm{C}$ and 3000 nauplii fish ${ }^{-1} \mathrm{~d}^{-1}$ group, on the other hand, $95 \%$ of survived fish remained in the Gu-0 stage. The ratio of Gu-0 stage fish increased with the decrease in food level in the 17 and $21^{\circ} \mathrm{C}$ temperature groups. The number of fish that survived in the 13 and $13^{\circ} \mathrm{C}$, and 30 and 300 nauplii fish ${ }^{-1} \mathrm{~d}^{-1}$ groups, respectively, were less than 5 , and were excluded from the analysis.

\section{DISCUSSION}

\section{Otolith IWs, somatic growth, and metamorphosis}

The mean IW during the second half of the $20 \mathrm{~d}$ rearing period $\left(\mathrm{IW}_{\text {exp }}\right.$ ) was linearly positively correlated with the mean growth rate during the second half of the rearing period $\left(G_{\text {exp }}\right.$ ) (Fig. 8). Larvae with a faster $G_{\text {exp }}$ metamorphosed from the larval (Gu-0) to the juvenile (Gu-2) stage in a higher proportion during the $20 \mathrm{~d}$ rearing period than those with a slower $G_{\exp }$ (Figs. $7 \& 9$ ). The larvae with a faster growth rate and shorter metamorphosing period were found to have larger IWs during late larval stage in Engraulis japonicus (Fig. 8). We found the same relationship among growth rates, metamorphosing period, and otolith IW in our field study; that is, the faster-growing Gu-1 stage pre-recruits in the younger age classes $\left(\mathrm{Cl}_{35}\right.$, $\mathrm{Cl}_{45}$ ) had larger IWs than the slower-growing prerecruits in the older age classes (Table 2, Fig. 3). The Gu-1 stage fish of younger ages had a shorter duration of metamorphosis than those of an older age (Takahashi 2001). Wright (1991) demonstrated that IW was positively correlated to the mean daily oxygen consumption in Atlantic salmon Salmo salar L. The IW in larval Atlantic herring Clupea harengus reflected the RNA:DNA ratio as an index of the nutritional condition in a rearing experiment (Folkvord et al. 1996). These findings suggest that IW positively correlates with the metabolic rate and energy intake, resulting in the 


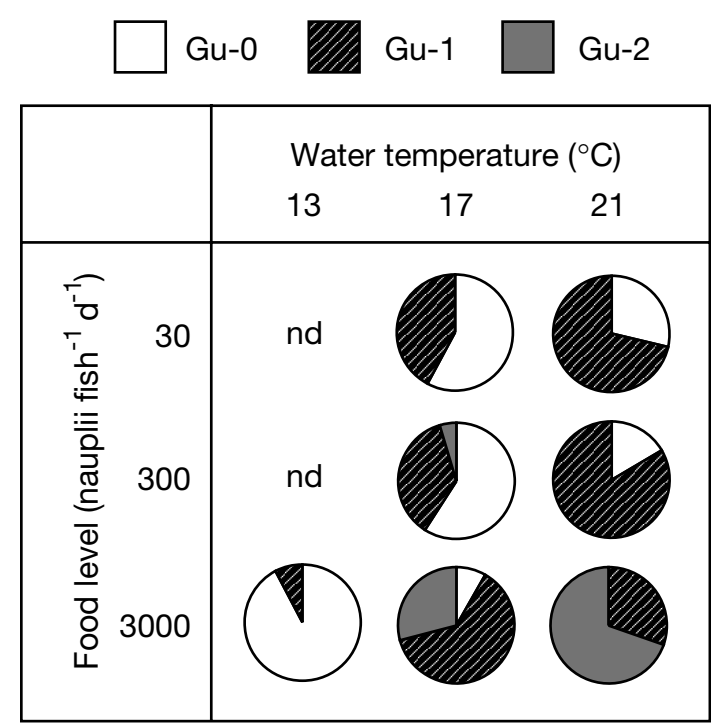

Fig. 9. Engraulis japonicus. Proportions in the number of surviving fish in the Gu-0, Gu-1 and Gu-2 stages (see 'Sample processing' for details) at the end of the $20 \mathrm{~d}$ rearing. nd: no data

growth and developmental rates during the larval stage in E. japonicus.

The mean IW in the recruits increased up to ca. $16 \mu \mathrm{m}$ and then gradually decreased (Fig. 4), while the Gu-1 stage pre-recruits had no obvious peak of IW in any age class (Fig. 3). The mean age at the peak of IW (53 d) in the recruits was comparable to the mean age at the Gu-1 stage (54.2 $\pm 10.2 \mathrm{~d})$. Juvenile northern anchovy Engraulis mordax also have been shown to have a peak of IW at $80 \mathrm{~d}$ and ca. $40 \mathrm{~mm}$ SL (Butler 1989). These data approximately correspond to SL and age at metamorphosis which occurs at about $35 \mathrm{~mm}$ SL and $70 \mathrm{~d}$ (Hunter 1976). Ohshimo et al. (1997) found that IW in juvenile Japanese sardine Sardinops melanostictus peaked at ca. $30 \mathrm{~d}$, and suggested that this was associated with metamorphosis. In clupeoid fish, the age at the peak of IW appears to correspond to the end of the metamorphosing (Gu-1) stage from larva to juvenile. The relationship between body length and otolith radius changed from allometric in the larval stage to linear in the juvenile stage in E. mordax (Butler 1987), Clupea harengus (Moksness \& Fossum 1992), S. melanostictus (Watanabe \& Kuroki 1997) and E. japonicus (Takahashi et al. 2001). As the otolith radius is a sum of IW at ages, the inflection point of the body lengthotolith radius relationship seems to coincide with the age at maximum IW in clupeoid fishes.

Based on the mesh retention theory for anchovy larvae (Smith \& Richardson 1977), larvae with absolute mesh retention are those larger than the diagonal of a given mesh aperture. The diagonal of the mesh at the cod end of the trawl net in this study was $14 \mathrm{~mm}$, which corresponds to the body depth at the pectoral fin of $80 \mathrm{~mm}$ SL adult anchovy. Maximum SL of the Gu-1 stage anchovy in this study was $47.0 \mathrm{~mm}$, and therefore, all the size classes had the probability to be extruded through the mesh aperture. We do not know the difference of the probability by SL size classes of anchovy, but the SL range of Gu-1 stage fish in this study was much smaller than the SL of absolute retention $(80 \mathrm{~mm})$. Therefore, the effects of mesh sizeselectivity on the current results, if any exist, are assumed to be minimal. We collected a lot of prerecruit anchovies by the trawl net despite the presence of mesh extrusion in this study. Wild pre-recruit anchovy seemed to proceed from Gu-0 to Gu-2 stage with SL growth, as we observed in the rearing experiment.

\section{Recruits in 1999 were survivors of the 1998 hatched cohort}

The main spawning season of Engraulis japonicus extended from April to August from 1990 to 1995, when the population size was large (Zenitani et al. 1995). The mean age of the pre-recruits collected from mid-May to mid-June in this study was ca. $50 \mathrm{~d}$. They hatched predominantly in April early in the main spawning season. Cohorts hatched in April grew up to ca. $12 \mathrm{~cm}$ in $12 \mathrm{mo}$ in the 1950s, when the population size was large (Hayashi \& Kondo 1957).

The frequency distribution of IW in the recruits was similar to that in the pre-recruits at $30 \mathrm{~d}$ (Fig. 5). Considering that the otolith IW is a positive function of somatic growth and development as discussed above, the recruits collected in 1999 may have experienced growth and developmental processes in the early larval stage the same as those in the pre-recruits collected in 1998. Based on these reasons, we assumed in this study that the recruits caught in 1999 were the survivors of the pre-recruits that hatched in spring in the previous year in the Kuroshio-Oyashio transition region.

\section{Growth and developmental rate-dependent mortality in the metamorphosing stage}

The minimum IW at each age in the recruits of Engraulis japonicus represents the slowest possible growth rate of larvae for successful recruitment to the adult population. It increased from $4.8 \mu \mathrm{m}$ at $40 \mathrm{~d}$ to $11.0 \mu \mathrm{m}$ at $60 \mathrm{~d}$ (Table 3, Fig. 5). Using the relationship of $I_{\text {exp }}$ to $G_{\exp }$ in the rearing experiments (Fig. 8), the slowest possible growth rate for survival is calculated to be $0.25 \mathrm{~mm} \mathrm{~d}^{-1}$ at $40 \mathrm{~d}$ and $0.41 \mathrm{~mm} \mathrm{~d}^{-1}$ at $60 \mathrm{~d}$. 
The proportion in total number of the pre-recruits within the IW range of the recruits was $100 \%$ at $30 \mathrm{~d}$ (Table 3). These imply that all the pre-recruits of various growth rates examined in this study had a probability of survival to recruitment up to $30 \mathrm{~d}$. The proportion declined to $93.8 \%$ at $40 \mathrm{~d}$, and greatly declined with age. At $60 \mathrm{~d}, 58.7 \%$ of the pre-recruits were smaller in IW than the minimum IW of the recruits, $11.0 \mu \mathrm{m}$ (Table 3). The pre-recruits with a smaller IW than $11 \mu \mathrm{m}$, which were estimated to have been growing at rates smaller than $0.41 \mathrm{~mm} \mathrm{~d}^{-1}$, had no probability of survival to recruitment. Growth rate-dependent survival occurred from 40 to $60 \mathrm{~d}$, which fell within the age range of the $\mathrm{Gu}-1$ metamorphosing stage.

The proportion in number of Gu-0 stage pre-recruits within the IW range of the recruits was $100.0 \%$ at $30 \mathrm{~d}$, but this decreased to $0 \%$ at $60 \mathrm{~d}$. None of the prerecruits were able to survive if they stayed in the Gu-0 stage at $60 \mathrm{~d}$. If they had advanced to the Gu-2 stage by $60 \mathrm{~d}$, they had a $72.5 \%$ probability of survival to recruitment (Table 3). This indicates that the survival probability is a function of development. We considered that developmental rate-dependent mortality as well as growth rate-dependent mortality occurred in the metamorphosing stage. In this study, it was confirmed that the faster-growing Engraulis japonicus larvae metamorphosed at a younger age and had a higher probability of survival to recruitment in the Kuroshio-Oyashio transition region.

Metamorphosis in fishes consists of a large transformation of the internal and external morphology, which is often related to ecological and habitat changes. The number of layers in the trunk red muscle rapidly increased from 2-3 to $7-8$ in the late larval stage (20 to $35 \mathrm{~mm}$ SL) in Engraulis mordax (Hunter \& Coyne 1988). The ability of larval and juvenile E. mordax to escape from predatory juvenile chub mackerel Scomber japonicus sharply increased by $30 \mathrm{~mm}$ SL in a rearing experiment (Folkvord \& Hunter 1986), resulting directly from the changes in the muscular system and the sense organs. Larval and juvenile E. japonicus are reported to be a preferred prey of skipjack tuna Katsuwonus pelamis and the mackerels $S$. japonicus and $S$. australasicus in the Kuroshio-Oyashio transition region (Nihira 1996, Watanabe et al. 1999). Delayed growth and development in a cohort will increase the vulnerability to predation in the metamorphosing period in $E$. japonicus in the Kuroshio-Oyashio transition region.

The 'critical period' hypothesis which stated that food limitation after yolk absorption (first-feeding stage) affects the subsequent survival rate was proposed in the early 20th century (Hjort 1914). After about half a century, the 'critical period' hypothesis was embodied by the 'ocean stability' hypothesis (Lasker 1975) and by the 'match/mismatch' hypothesis (Cushing 1975).
Interannual variability in the abundance of post firstfeeding larvae, however, had no correlation with the abundance of the Age 1 recruit population in Engraulis mordax (Peterman et al. 1988), and in Sardinops melanostictus (Watanabe et al. 1995). In these studies, cumulative mortality through the larval and juvenile stages seemed to be responsible for determining abundance of recruits in clupeoid fishes. Our results indicate that the growth rate-dependent and the stage duration-dependent survival occurs in the metamorphosing stage in E. japonicus, and could explain the discrepancy of abundances between post firstfeeding larvae and recruits in clupeoids.

\section{Environmental conditions in the SW waters}

The proportions in number of survived fish with $\mathrm{IW}_{\text {exp }}$ greater than $11 \mu \mathrm{m}$, which was the smallest IW in the recruits at $60 \mathrm{~d}$, were highest in the $21^{\circ} \mathrm{C}$ and 3000 nauplii fish ${ }^{-1} \mathrm{~d}^{-1}$ group among all the experimental conditions (Table 4). Sea surface temperature (SST) ranged from 13.4 to $19.7^{\circ} \mathrm{C}$ in the waters where larval and early juvenile Engraulis japonicus were distributed in the Kuroshio-Oyashio transition region, and was higher in the southern waters than in the northern waters in 1996 and 1997 (Takahashi et al. 2001). The mean available prey density for larval and early juvenile E. japonicus was $195 \mathrm{mg}$ dry weight $\mathrm{m}^{-2}$ in the western waters $\left(140\right.$ to $\left.155^{\circ} \mathrm{E}\right)$ and $42 \mathrm{mg}$ dry weight $\mathrm{m}^{-2}$ in the eastern waters (155 to $\left.170^{\circ} \mathrm{E}\right)$ in 1998 (Takahashi 2001). Growth and developmental rates in the Gu-1 pre-recruits were faster in the SW waters than in the northern or eastern waters in the transition region (Takahashi 2001). The SW waters seem to have preferable environmental conditions for the larval growth and development and contribute to the recruitment success in E. japonicus in the Kuroshio-Oyashio transition region.

According to the SST in $1^{\circ}$ grid (latitude $\times$ longitude) data sets from April to June over the western North Pacific (Japan Meteorological Agency), SST anomalies in the SW waters (36 to $38^{\circ} \mathrm{N}, 140$ to $150^{\circ} \mathrm{E}$ ) were mainly negative in the $1980 \mathrm{~s}$, while positive in the 1960s through the mid-1970s and in the 1990s in the transition region. A southern intrusion of the cold Oyashio water stayed around $38^{\circ} \mathrm{N}$ in the 1960 s and 1970 s, while in the 1980s markedly extended southward in the 141 to $146^{\circ} \mathrm{E}$ waters to around $36^{\circ} \mathrm{N}$ (Kawai 1989). The total annual catch of Engraulis japonicus in the Pacific coastal waters was 100000 to $250000 \mathrm{t}$ from the 1960s to mid-1970s, while it decreased to 50000-100000 through the 1980s and then rapidly increased from the 1990s (Statistics and Information Department 1963-1996). The current re- 
sults could explain the population fluctuation in E. japonicus in the Pacific stock as being due to the mechanisms which led to a cooler regime in the 1980s in the SW part of the transition region and, thus, caused a decrease in the larval growth rate and delay in metamorphosis, resulting in lower probability of survival to recruitment and a reduced total abundance of E. japonicus.

Acknowledgements. We are grateful to Dr. T. Kawamura, Ocean Research Institute, University of Tokyo, for critical comments on this manuscript. We thank Captain K. Niu and the crew of the RV 'Tanshu-Maru' for their assistance in collecting field samples. We also thank Mr. K. Morita, Drs. M. Amano and Y. Takagi, Otsuchi Marine Research Center, Ocean Research Institute, for their assistance with the rearing experiment. This study was supported in part by Japanese Society for the Promotion of Science (JSPS) fellowships for Japanese Junior Scientist and a Grant-in-aid for Scientific Research from the Ministry of Education, Science and Culture, Japan.

\section{LITERATURE CITED}

Anderson JT (1988) A review of size-dependent survival during pre-recruit stages of fishes in relation to recruitment. J Northwest Atl Fish Sci 8:55-66

Bailey KM, Houde ED (1989) Predation on eggs and larvae and the recruitment problem. Adv Mar Biol 25:1-83

Butler JL (1987) Comparison of larval and juvenile growth and larval specific interactions. PhD thesis, University of California, San Diego

Butler JL (1989) Growth during larval and juvenile stages of the northern anchovy, Engraulis mordax, in the California Current during 1980-84. Fish Bull 87:645-652

Campana SE (1990) How reliable are growth back-calculations based on otoliths? Can J Fish Aquat Sci 47:2219-2227

Campana SE, Jones CM (1992) Analysis of otolith microstructure data. In: Stevenson DK, Campana SE (eds) Otolith microstructure examination and analysis. Can Spec Publ Fish Aquat Sci 117:73-100

Cushing DH (1975) Marine ecology and fisheries. Cambridge University Press, Cambridge

Folkvord A, Hunter JR (1986) Size-specific vulnerability of northern anchovy, Engraulis mordax, larvae to predation by fishes. Fish Bull (Wash DC) 84:859-869

Folkvord A, Ystanes L, Johannessen A, Moksness E (1996) RNA:DNA ratios and growth of herring (Clupea harengus L.) larvae reared in mesocosms. Mar Biol 126:591-602

Fukuhara O (1983) Development and growth of laboratory reared, Engraulis japonicus (Houttuyn), larvae. J Fish Biol 23:641-652

Funamoto T, Aoki I (2002) Reproductive ecology of Japanese anchovy off the Pacific coast of eastern Honshu, Japan. J Fish Biol 60:154-169

Hare JA, Cowen RK (1997) Size, growth, development, and survival of the planktonic larvae of Pomatomus saltatrix (Pisces: Pomatomidae). Ecology 78:2415-2431

Hayashi S, Kondo K (1957) Growth of the Japanese anchovy-IV. Age determination with use of scales. Bull Tokai Reg Fish Res Lab 17:31-64

Heath MH, Zenitani Y, Watanabe Y, Kimura R, Ishida M (1998) Modelling the dispersal of larval Japanese sardine,
Sardinops melanostictus, by the Kuroshio Current in 1993 and 1994. Fish Oceanogr 7:335-346

Hjort J (1914) Fluctuations in the great fisheries of northern Europe viewed in light of biological research. Rapp p-v Réun Cons Int Explor Mer 20:1-228

Hunter JR (1976) Culture and growth of northern anchovy, Engraulis mordax, larvae. Fish Bull (Wash DC) 74:81-88

Hunter JR, Coyne KM (1988) The onset of schooling in northern anchovy larvae, Engraulis mordax. Calif Coop Oceanic Fish Invest Rep 23:246-251

Kasai A, Kishi JJ, Sugimoto T (1992) Modelling the transport and survival of Japanese sardine larvae in and around the Kuroshio Current. Fish Oceanogr 1:1-10

Kawai H (1972) Hydrography of Kuroshio Extension. In: Stommel H, Yoshida K (eds) Kuroshio: its physical aspects. University of Tokyo Press, Tokyo, p 235-252

Kawai H (1989) Long-term fluctuations in the north limit of the Kuroshio Extension axis and in the south limit of the Oyashio water near the east coast of Japan. Bull Jpn Soc Fish Oceanogr 53:353-363

Kuroda K (1991) Studies on the recruitment process focusing on the early life history of the Japanese sardine, Sardinops melanostictus (SCHLEGEL). Bull Natl Res Inst Fish Sci 3: 25-278

Lasker R (1975) Field criteria for survival of anchovy larvae: the relation between inshore chlorophyll maximum layers and successful first feeding. Fish Bull 73:453-462

Meekan MG, Fortier L (1996) Selection for fast growth during the larval life of Atlantic cod Gadus morhua on the Scotian Shelf. Mar Ecol Prog Ser 137:25-37

Miller TJ, Crowder LB, Rice JA, Marschall EA (1988) Larval size and recruitment mechanisms in fishes: toward a conceptual framework. Can J Fish Aquat Sci 45:1657-1670

Mitani I (1990) The biological studies on the larvae of Japanese anchovy, Engraulis japonica HOUTTUYN, in Sagami Bay. Spec Rep Kanagawa Prefect Fish Exp Stn 5:1-140

Moksness E, Fossum P (1992) Daily growth rate and hatchingdate distribution of Norweigan spring-spawning herring (Clupea harengus L.). ICES J Mar Sci 49:217-221

Moksness E, Rukan K, Ystanes L, Folkvord A, Johannessen A (1995) Comparison of somatic and otolith growth in North Sea herring (Clupea harengus L.) larvae: evaluation of growth dynamics in mesocosms. In: Secor DH, Dean JM, Campana SE (eds) Recent developments in fish otolith research. University of South Carolina Press, Columbia, p 119-134

Mugiya Y, Watabe N, Yamada J, Dean JM, Dunkerberger DG, Shimizu M (1981) Diurnal rhythm in otolith formation in the goldfish, Carassius auratus. Comp Biochem Physiol 68A:659-662

Nihira A (1996) Studies of the behavioral ecology and physiology of migratory fish schools of skipjack tuna (Katsuwonus pelamis) in the oceanic frontal area. Bull Tohoku Natl Fish Res Inst 58:137-233

Odate K (1994) Zooplankton biomass and its long-term variation in the western North Pacific Ocean, Tohoku sea area, Japan. Bull Tohoku Natl Fish Res Inst 56:115-173

Odate S (1957) Study on the larval fish of the Japanese anchovy, Engraulis japonica (HOUTTUYN), in the northeastern sea area of Japan. Bull Tohoku Natl Fish Res Inst 9:111-128

Ohshimo S, Nagatani H, Ichimura T (1997) Growth of 0-age Japanese sardine Sardinops melanosticuts in the waters of the western coast of Kyusyu. Fish Sci 63:659-663

Okazaki Y, Nakata H, Kimura S (2002) Effects of eddies on the distribution and food availability of anchovy larvae in the Kuroshio Extension. Mar Freshw Res 53:403-410 
Pannella G (1971) Fish otoliths: daily growth layers and periodical patterns. Science 173:1124-1127

Paperno R, Targett TE, Grecay PA (1997) Daily growth increments in otoliths of juvenile weakfish, Cynoscion regalis: experimental assessment of changes in increment width with changes in feeding rate, growth rate, and condition factor. Fish Bull (Wash DC) 95:521-529

Peterman R, Bradford MJ, Lo NCH, Methot RD (1988) Contribution of early life stages to interannual variability in recruitment of northern anochovy (Engraulis mordax). Can J Fish Aquat Sci 45:8-16

Secor DH, Dean JM, Baldevarona RB (1989) Comparison of otolith growth and somatic growth in larval and juvenile fishes based on otolith/fish length relationship. Rapp p-v Réun Cons Int Explor Mer 191:431-438

Sigel RB (1988) Population dynamics of the Japanese anchovy, Engraulis japonicus, SHIRASU of the EnshuNada and Ise Bay fishery, Japan revealed through otolith daily increments. PhD thesis, University of Tokyo

Smith PE, Richardson SL (1977) Standard techniques for pelagic fish egg and larva survey. FAO Fish Tech Pap 175:1-99

Statistics and Information Department (1963-1996) Annual statistics on fisheries and aquaculture production. Tokyo

Takahashi M (2001) Growth and development of larval and juvenile Japanese anchovy (Engraulis japonicus) and their implications for recruitment to spawning population. $\mathrm{PhD}$ thesis, University of Tokyo

Takahashi M, Watanabe Y (in press) Staging larval and early juvenile Japanaese anchovy Engraulis japonicus (Houttuyn) based on the degree of guanine deposition. J Fish Biol

Editorial responsibility: Otto Kinne (Editor),

Oldendorf/Luhe, Germany
Takahashi M, Watanabe Y, Kinoshita T, Watanabe C (2001) Growth of larval and early juvenile Japanese anchovy, Engraulis japonicus, in the Kuroshio-Oyashio transition region. Fish Oceanogr 10:235-247

Tanaka K, Mugiya Y, Yamada J (1981) Effects of photoperiod and feeding on daily growth patterns in otoliths of juvenile Tilapia nilotica. Fish Bull 79:459-466

Tsuji S (1983) Study on recruitment mechanism of larval anchovy to shirasu fishing grounds in Sagami Bay based upon otolith daily increment analyses. PhD thesis, University of Tokyo

Watanabe C, Kawabata A, Wada T (1999) Distribution of 0 -year cohorts in Scomber fish in the Kuroshio-Oyashio transition region. Kakiyo Monthly 31:236-240

Watanabe Y, Kuroki T (1997) Asymptotic growth trajectories of larval sardine Sardinops melanostictus in the coastal waters off western Japan. Mar Biol 127:369-378

Watanabe Y, Zenitani H, Kimura R (1995) Population decline of the Japanese sardine Sardinops melanostictus owing to recruitment failures. Can J Fish Aquat Sci 52: 1609-1616

Wright PJ (1991) The influence of metabolic rate on otolith increment width in Atlantic salmon parr, Salmo salar L. J Fish Biol 38:929-933

Zenitani H, Asano K (1996) Spawning of Japanese anchovy in the Japanese Pacific coastal region. Fish Sci 60: $416-418$

Zenitani H, Ishida M, Konishi T, Goto T, Watanabe Y, Kimura R (1995) Distribution of eggs and larvae of pelagic fish species around Japan. Series A-1:1-368, Resources Management Research Report, National Research Institute of Fisheries Science, Yokohama

Submitted: May 13, 2003; Accepted: October 14, 2003

Proofs received from author(s): December 24, 2003 